\title{
Determinants of the Regional Role of Qatar
}

\author{
Nouf Saud Al-Maatouk ${ }^{1} \&$ Mohamed Kama $^{1}$ \\ ${ }^{1}$ Faculty of Economics and Political Science, Cairo University, Egypt \\ Correspondence: Nouf Saud Al-Maatouk, Faculty of Economics and Political Science, Cairo University, Egypt. \\ E-mail: rn.adham@gmail.com
}

Received: March 3, 2017

doi:10.5539/jpl.v10n3p191
Accepted: March 24, 2017 Online Published: June 1, 2017

URL: https://doi.org/10.5539/jpl.v10n3p191

\begin{abstract}
Abstact
Aim: The present study aims to demonstrate the passive and active impact for the regional role of Qatar which played heavily on the Middle East countries through the limitations and capabilities possessed by the performance of this regional role towards the countries of the region's issues that could be detrimental to the strategic interests. Methodology: The researcher fellowed a descriptive analytical methodology for description and analysis of a scientific phenomenon of Qatar's role on the Middle East countries through the limitations and capabilities possessed by the performance of this regional role towards the countries of the region's issues that could be detrimental to the strategic interests. Results: The current study has revealed 3 main points: $1^{\text {st }}$ The national policy regional and international roles selectors are not in accordance with the standards of the international force generally accepted in the political and strategic doctrine, $2^{\text {nd }}$ The Consequent obligations calculated in the framework of the competition between the major powers, but according to the size of the state in terms of the location, population and limited capabilities in the regional competition and $3^{\text {rd }}$ was that Physical force, and political statesmanship can be substituted in the diplomatic game management, all the way to the strategic goals and the task of maintaining the state and its political system that burgles them, not by the big powers, but by competing regional powers to dominate the region. Conclusion: Qatar plays a key role in the Middle East region. This role mainly connected to the size of determinants, elements, and potentials, which constitute the elements of the State of Qatar's power. The size of the impact of the State's role could be expected, according to the tasks have been undertaken by the State, which depend on the potentials of the state.
\end{abstract}

Keywords: determinants, regional role, Qatar

\section{Introduction}

This study is about the pursuit of Qatar with its significant in the Middle East region, whether positively or negatively through determinants and capabilities, it has to undertake such regional role towards the countries of the region's issues that they could affect negatively on its strategic interests. The pursuit of the State of Qatar to play influential roles in the international systems makes the decision-makers realize the necessity to work through international organizations, activate their membership, and participate in various international and regional forums. This matter granted Qatar a strong base of the successful diplomatic action and an experience in hosting and organizing important global conferences. Thus, this study is divided into three chapters: The first chapter deals with the types of Qatari domestic determinants; the second addresses the determinants of the Qatari role concerning the regional system; and the third displays the regional powers competing for the role of Qatar.

\section{Method}

\subsection{The Study Problem}

Given the role played by Qatar as an emerging and growing regional power in the Middle East region, in moving the regional political situation to serve its national and strategic interests, the research problem concerns with the limits of the role could be played by Qatar in its regional boundaries and its impact on the regional system to which belongs. Accordingly, the study tries to answer to the main question: what is the nature of determinates of the regional role of Qatar. Then, there are the following subsidiary questions of the main question, which are: What are the internal determinants of the State of Qatar,whether there isany correlation between the Qatari determinants and the regional system surrounding it.And Which are the competitive forces of Qatar in its regional surrounding. 


\subsection{The Significance of Study}

The study contributes to the academic accumulation related to the role of the determinants of small States, and to studies on international relations regionally through knowing the mechanisms of the working regional role. The study seeks to demonstrate the Qatar's role, and the patterns of its regional dealing towards the Middle East's transformations. It is an attempt by the researcher to develop analytical and scientific frameworks for analyzing the Qatari role in its territory in terms of the determinants of this role, and the types of tools used in activating this role, making it influential in the Middle East.

\subsection{The Limits of Study}

The place of the study is the Middle East. Choosing this region is due to the positive and negative developments, as well as transformations at the regional level that occurred in this region. The study tries to demonstrate the role of the smaller States in this region that have active issues and development mobility during the study period. Thus, selecting the study of the role of Qatar towards the Middle East region was due to scientific and objective considerations. This role is represented in the importance of studying its dimensions and knowing the points of the weakness and strength of Qatar's role in the region in order to create creating an integrated vision on how to deal with this role and its consequences and implications.

\subsection{Basic Concepts}

The concept of small States: This concept is defined as a category of sovereign countries. However, these states occupy a low rank in one or more of the fields of economic, political, military or democratic. In addition, they are defined as the countries that cannot provide security for themselves initially by using their own specific capabilities, the matter that requires mainly relying on the help of others (Jeane H., 2003). As stated above, it is clear that Qatar, despite its small geographical size, occupies a central place in the territory of the Middle East region for what it plays of roles in this troubled region.

The concept of the role: The concept of the role is one of the central concepts that was used by literature of foreign policy to understand the behaviors and decisions of foreign policy of the different international units, and the possibilities of change and continuity in this policy (salam M.A., 2008). The concept of the role has been crystallized to raise to the rank of theory, where the role theory is considered more predictability of the foreign policy of the States than the theories of new realism, liberalism, imperative materialism, and strategic doctrines (salam M.A., 2008).

The concept of the regional role: In the framework of the regional role of one of the units of the regional system, it is found that the regional role is connected to the power sources possessed by each unit in terms of military and economic forces, and to the extent of what it represents the ideology providing a moral energy. It is one of the sources of power and the distribution of the power structure is among multiple units, where each unit could possess just a relative superiority in one of the sources of power without giving preponderance to each State to possess more than one source. This situation affected the region by losing the element of the regional leadership.The regional role of a State does not arise until it is seeking to play and formulate deliberately and consciously this role. On the other hand, such role needs the recognition of both the regional and international environment in order to be stable, continuous and effective (Aliwi M., 1996).

\section{Results}

\subsection{The Domestic Determinants of Qatar}

Every State seeks, in the domain of its international and regional relations, to make its foreign policy embodied for its human, economic and military capabilities, and to be the potential of its interaction effectively in its regional surroundings. This matter requires maintaining its national interests and territorial integrity where any State's foreign policy is a reflection of its internal policy and political decision - makers in it. In other words, it reflects the leader of power's philosophy.Therefore, Qatar's conduct and role emerge from internal policies relating to the Qatari political system, as well as the nature of the social and demographic structure of Qatari demography being a tribal State ruled by these frameworks. Accordingly, Qatar is seeking, through the following determinants, to have an influential regional role.

\subsubsection{Political Decision-Maker}

Which formulates and determines a State's policy according to his understanding and conception of the objective variables, not according to the importance of these variables. This confirms that the internal and external environment with its all dimensions, content and basic elements not as much as the importance due to how they are conceived by the concerned parties, who are responsible in putting these policies (Maklad I.S., 1987). 
Accordingly, the decision-maker enjoys a set of personal characteristics that affect the style of his formulation of the decisions of foreign policy and the way he deals with them. The political leader acquires these qualities and characteristics through the different stages of his life, such as the ability to innovate, the adventurous spirit he has, and the ability to face and deal with a mysterious situation (Al Kafma A.A. 2009) The empirical studies in the psychology and politics science has proved that the individual has a significant role that may exceed the other structural forces in making political decisions in the third world countries. This is because of their circumstances, which have not yet been able through its political experience to enhance the State institutions by taking institutional decisions (Alkafma A.A. 2009) According to the role theory, taking the political decision depends on the role played by a decision maker, and the position he occupies, whether as the president of State, foreign minister or delegate to the United Nations. This position makes him obligated to act according to a particular pattern of behavior in the political decision-making internally and externally. In addition, decision-maker's personality is a key and influential factor in shaping the State's foreign policy.

In addition, the behavioral school gives a personal decision maker a central role in the decision- making process. Political decision- maker in the majority of developing countries plays a key role in a decision-making due to the low level of efficiency in management performance, the absence of real political participation, and the weak capabilities of responding these systems (Aliwa A. 1978).

As for political decision- making in Qatar, we find that the Qatari regimen is based on a hereditary sheikhdom rule where Al -Thani family, who has a historical and social status, still rules the country, and the Sheikh is the country's prince and Supreme commander of the army (Al Zaidi M, 2000). The impact of the role of the prince on the political decision has appeared since taking over Sheikh Khalifa bin Hamad Al Khalifa the rule in 1972, where he played a key role in establishing distinguished relations with Saudi Arabia. These good relations led to signing the bilateral defense agreement between them in 1981, as well as Qatar's accession to the Gulf Cooperation Council (Qasem J.Z. 1914). After the appointment of Sheikh Hamad bin Khalifa Al Thani as the governor of Qatar in 1995, the Qatari political decision significantly influenced by shifts on all political, economic and social levels. At this time, Qatar came in the forefront of the Gulf States concerning the level of regional and international relations. This was due to the orientations of the ruler, who wanted to make Qatar distinguished by its role in the political arena regionally and internationally.

Thus, it is hard to explain Qatar's foreign policy away from the beliefs, perceptions and personal motivations of the Qatari leadership. Qatar prince, Sheikh Hamad Al Thani has been had political ambitions and trends. Also, the Prime Minister of Qatar was active concerning external behavior's decisions(Qandil H. ), the intensify of contacts with the outside world, expanding relations with African, Asian and Latin American countries, and deepening relations with Arab, European and American countries. Therefore, the Qatari foreign policy has directed to penetrate the Arab and strategic traditions and to open to European countries and the United States, and to gain support in the openness to the concepts of the governance, policy, and walking in a democratic step.

The change in the Qatar's policy is now in its heritage and in Arab politics as well through practicing the rule to find a State practicing the authority whose interests are in achieving democracy such as constitution, parliament, elections, free media and market. In addition to the recognition as it a small geographical size, which has been historically associated with the disputes of the political borders with neighboring countries and the region(AlAfifi F., 2003).

\subsubsection{The Level of Economic Progress}

The ability of Qatar to play the roles of its foreign policy depends dramatically on its economic resources. Qatar has used natural gas within its policy towards integration with the global economy. In addition, it has benefited from its economic capabilities to success in a number of mediation files in more than one conflict. Qatar has oil reserves of up to 25.4 billion barrels. It is the third of the global reserves of natural gas estimated at 896 trillion cubic feet and it is the first exporter of liquefied natural gas in the world. In 2012, Qatar recorded the highest economic growth and the exports of oil and natural gas were more than half of Qatar's revenues. Furthermore, it has the highest income of per capita in the world. According to the International Monetary Fund (IMF), the average of per capita income rose from $\$ 7700$ in 2009 to reach $\$ 106$ in 2012(Abdullah M., 2012). These Qatari economic achievements were due to strategies adopted by the State such as the development of oil production, the optimum exploitation of the state's wealth, the development of the state's institutions, the establishment of public bodies for tourism, works, and urban planning and development. These matters are important signs to modernize the economic systems, as well as make room for the private sector and ignite the spirit of competition.

In this context, Qatar is keen to expand regionally and internationally in more than one place. The Qatari and Ukrainian cooperation in the field of energy in November 2012 was an example of this expansion. According to 
agreements made between the two countries, Qatar may become the gate of the Ukrainian grains to the Gulf States and the Middle East, where it expressed its willingness to invest in feed grain cultivation and Ukrainian wheat sales in the Arab countries. In return, Ukraine gets liquefied natural gas from Qatar. We believed that Qatar reorted to this expansion for the following reasons: I-Economic benefits that Qatar will get due to the cooperation with Ukraine, which will be able to strengthen its presence in the European energy, market'Allush F., 2012. II- Qatar's active role in the former Soviet Union, especially the Baltic States, and the agreements made between Qatar and the Republics of Tajikistan and Kyrgyzstan about inviting workers to Qatar. In addition to the establishment an investment fund of $\$ 100$ million by Qatar to improve the Tajik economy. All previous matters made many Russian experts think that Qatar's foreign policy stands in the face of Russian Federation (Allush F., 2012).III- Qatar adopts the free economy policy, enacts legislations and updates them continuously in order to establish and support such economic orientation opening to all countries of the world. Furthermore, there are no customs restrictions on business and financial transfers to abroad(Al Rantisi M.s., 2013) IV- Qatar has several internal elements to attract foreign investments, most notably the political and social stability. In addition, it does not impose any restrictions on the transactions of the financial transfers, as well as on the entry and exit of capital from the state. Many specialists believe that Qatar's economic strength is the first pillar from which the Qatari role stems, the matter that appeared since the mid-1990s.

\subsection{Determinants Related to the Regional System}

Numerous determinates emerging from the regional environment surrounding the State of Qatar which have an impact on the orientations of the Qatari foreign policy and its regional roles. Hence, the determinants of the Qatari policy and its regional and international roles emerge from this public trend. It is not emerged according to the standards of the generally accepted international power in the political and strategic doctrine, and the consequent obligations calculated within the framework of competition among the major powers. It is emerged according to the size of the State in terms of location, population and its limited capacity in the regional competition, and what can be a compensation this in the financial force and statesmanship in managing of the diplomatic game until achieving strategic goals represented in maintaining the State and its political system that controlled not by the competing regional powers, but by the rival regional hegemony on the region(Nathem A.).

\subsubsection{The Exploitation of the Qatari Oil Wealth}

The Qatari government has tended to diversify the sources of national income and reduce reliance on a single source of income. The State was keen to achieve a positive balance between the requirements of the development plans on the one hand, and the requirements of the global market of oil and natural gas on the other hand(Bin-Eid M., 1992). Oil and gas sector plays a vital role in drawing the Qatari foreign policy and this oil wealth of the State of Qatar helped in development support for many countries, as it accounts for a prominent position among the Arab countries. Therefore, gas was considered one of the most important pillars on which Qatar depends in formulating its political role, where it has spent more than $\$ 120$ billion on the infrastructure of liquefied natural gas.

In 2006, Qatar topped in the front of gas exporting countries globally, surpassing Indonesia (Orliks Ch., 1979). Significantly, the economic factor is not less important than the other factors according to the requirements of modernization. Economy grants the foreign policy the potentials of independence and effectiveness where any state is not able to dispense with a sound and strong economic base in its foreign policy(OriliksCh., 1979). This factor attracts the interest of Qatari Leadership internally and externally. Eternally, the political leaderships in Qatar considered it as sponsored and welfare state. Externally, the economic factor affected the inevitability of moving in the direction of organizing its economic activity, as well as this factor granted Qatar significant financial potentials in moving towards the external policy(Bin-Eid M., 1992). Qatar has great economic potentials in the field of energy. Therefore, it used large financial surplus in promoting its economic influence abroad. For example, it exploited the financial crisis of 2008 by the Qatari Investment Authority, in addition to the investments of Princes of the Royal Family in the great global corporates. These investments were in sports field, as well as major shares in the global and regional banks. In addition, it is working seriously to expand the Qatari investments in many areas in the Middle East and North Africa(Orliks Ch., 1979 ).

\subsubsection{The Political Media}

The nineties of the twentieth century witnessed great developments in the Arab satellite channels through the live broadcast along the Arab area between the Arab local satellite channels and the other ones in the West. This Phenomenon was an evidence of the growing popularity of new media and the dissatisfaction of many Arabs about the coverage the visual media of government for the regional issues and home affairs (Ghareeb E. \&Mansour K., 2002). 
Among these stations and channels emerged Al-Jazeera channel, which has chosen an advanced technology system to display the live reports and the different cultural and economic programs. In addition, it established its offices in several Arab and Foreign cities and capitals (Ayish M., 2001). The success and strength of this media channel emerged in displaying a combination of bold news and talk shows, which attracted many political dissidents, Islamic militants and those interested in human rights. It has proved success in a short period by achieving significant media achievements at the Arab and international levels. The importance of this channel increased in September 2001 events, and after its coverage of the war in Afghanistan and continuing news broadcast where these news reached the US and European spectators and turned to the voice of the Middle East in the West(vassal M., 2002). Qatar benefited from activating the political media by exploiting the international and regional crisis the world has witnessed since 2001, and continued in 2002. Thus, in the following years, the channel has increased in expansion and its place, and increased the attracting viewers over the world as a result of the live media coverage of events in professional manner(El-Zaidi M., 2003).

\subsection{The Determinants Related to the Policies of Regional Powers Competing to the State of Qatar}

The Qatari policy has witnessed shifts in dealings with its geopolitical surrounding. This policy was characterized by neutrality during the first decade of the third millennium. However, Qatar's foreign policy path has changed to become influential and effective one by adopting the positions of support for the Arab Spring revolutions in the Middle East. Thus, the Qatari strategy sought to make balance among the powers of the region by supporting countries' emerging powers in which change has occurred. For example, it has supported Islamism trend, which put the Qatari policy in a cautious position about provoking the northern neighbor (Iran) on the one hand, and some Arab Gulf States on the other hand. This matter made Qatar's foreign policy and regional role in a competitive position with the policies of the other powers in the region as follows:

\subsubsection{The Kingdom of Saudi Arabia}

There is a competition between Qatar and Saudi Arabia, where Qatar's emerging power has various repercussions on the position of the other rich countries in the Arab Gulf region, especially Saudi Arabia, the dominant power in the Arab world. It is clear that there is a competition between the two countries, but it does not a competition effect on the region's security negatively. Qatar has strong business relations with both Saudi Arabia and the United Arab Emirates. Furthermore, expanding the Arab economic cooperation through specifically the Gulf Cooperation Council makes the possibility of conflict breaking out between these states quite far(Audah J.). Such this competitive relationship, although it is based on mutual mistrust, is characterized by calm due to the mutual interest between them. They are seeking to reach a compromise about some issues affecting the interests of the two parties in the region by limiting the proliferation of Islamic Movements' policies and negative attitudes towards the Islamic Republic of Iran.

In the light of the Arab mobility, the Saudi - Qatari relations were differentiated. In the one hand, the two parties have agreed on some issues and on other hand, they disagreed on others. In the Tunisian and Egyptian cases, the disagreement has appeared and contrasted in the positions of both parties, where the Saudi situation was cautious and dismissive of this mobilization, while Qatar supported this mobilization in both countries. This situations remained unchanged where Saudi Arabia was supporting Muslim Brotherhood's opponents, while Qatar was supporting Muslim Brotherhood with all economic and media means(Zaki M.A., 2014). The disagreement between the two countries appeared in Egyptian crisis also where Qatar supported the Muslim Brotherhood and the toppled President Mohamed Morsi, while Saudi Arabia supported strongly demonstrations of 30 June 2013. In addition, it granted Egypt more than $\$ 7$ billion(Zaki M.A., 2014). On the other hand, two parties were agreed about the mobilization in both Libya and Syria, and Yemen just in a particular time. The two parties exploited their influence in the Arab league, especially under the Leadership of Qatar of the rotating presidency of the Arab league's sessions, passing a number of progressive steps against both Muammer Al Gaddafi and Bashar Al Assad's regimes (Amin et al. ).

\subsubsection{Arab Republic of Egypt}

The relationship between Egypt and Qatar in the eighties and nineties of the last century was strong like Egypt's relationship with the other Arab Gulf countries. Sheikh Khalifa Al - Thani, the Prince of Qatar, and Hosni Mubarak, the former President of Egypt, established a friendly relationship between each other, where many economic and residential projects have been launched in Egypt. However, after a bloodless coup in Qatar in 1995, and Sheikh Hamad bin Khalifa took power, this coup was against Egypt coincided with the Gulf situation, especially Saudi Arabia (Moujali N., 2013).

These resulted in tension in the Egyptian - Qatari relationship, followed by a clash and rupture in relations between them. Competition policy that prevailed between the two leaderships in both countries and seeking 
Qatar to find a pivotal role in the region contributed to fuel the Egyptian - Qatari relationship. Qatar sought to play a role in issues within the Egyptian vital influence such as Sudan and Palestine ( Kareem A.A., 2009). However, these facts highlighted the motive of the State of Qatar in its pursuit of the Arab leadership at the expense of the Arab Republic of Egypt and the exploitation of the decline of the regional role in the Egyptian international levels. The attributes of the Qatari - Egyptian relationship were evident in protest of January 2011, which resulted in the overthrow of the strongest opponent of Qatari regime. The Qatari media tool played a significant role in achieving this matter. In the era of the Military Council, Qatar adopted partly balanced stances, and granted Egypt some aids that were not provided previously. However, in the era of president Mohamed Morsi, Qatar was an ally and a strong supporter for Muslim Brotherhood, which exposed a popular and media campaign for criticism due to its biased situation. This campaign led to a case of skepticism regarding its role in the region; also, it was accused of implementing Western projects, especially American ones, to re-divide the Arab countries within the Middle East project.

Some Egyptian political forces called for boycott of diplomatic relations with Qatar under the pretext of intervention in others' affairs and incitement to commit violence. Therefore, Egypt returned the Qatari deposit that has been granted to Egypt in the era of former President Mohamed Morsi.

\section{Conclusion}

Accordingly, Qatar plays a key role in the Middle East region. This role mainly connected to the size of determinants, elements, and potentials, which constitute the elements of the State of Qatar's power. The size of the impact of the State's role could be expected, according to the tasks have been undertaken by the State, which depend on the potentials of the state.

\section{References}

Al Tamimi, cit, p 63.

Alsaid Aliwa: the Decision Approach in the Analytic of Political Systems, the Center for Research and Political Studies, the University of Cairo, 1978, the University of Cairo, p 145.

Amin and Others, Qatar: Aspirations and realities, op, cit, p37.

Amr Abdul Kareem, Qatar and the Regional Role, the Egyptians, 7/12/2009.

Aref Ahmed Al Kafarna, the Influential Factors in the Decision-Making Process in the Foreign Policy, Journal of International Studies, the Center for International Studies, University of Baghdad, Issue (42), 2009, p.35-36.

Atheir Nathem, cit, p 129-130.

Christian Orliks, cit . 24. Mohamed Obaidan, the Political Institutions in the State of Qatar, Master Thesis, the University of Cairo, 1979, pp. 32-36.

Edmond Ghareeb and Khaled Mansour, Arab Media on the Outskirts of Twenty - First Century: between the Hammer of Globalization and the Anvil of the State in Media and Communication in our Communities, the Sixth Book, 1999-2000, p34.

Farid Alloush, The Qatari - Ukraine Cooperation in the Field of Energy, the Center of Al Jazeera for Studies, in Arabic: http://studies.aljazeera.net/reporrts/2012/12/20122463443270206.htm

Farid Alloush: Qatar Ukraine Cooperation in the Field of Energy, Al Jazeera Center for Studies. http://studies.aljazeera.net/reporrts/2012/12/20122463443270206.htm

Fathy Alafifi : the Democracy and Liberalism in the Political Practices of the State of Qatar, the Journal of Arab Future, issue 298, December 2003,pp 50-52.

Hatem Qandil: the Foreign Policy of Qatar towards Arab- Israel Conflict under the rule of Sheikh Hamad ben Khalifa Al Thani, an unpublished Master Thesis, the Institute of Research, the University of Cairo, p30.

Hatem Qandil: the Foreign Policy of Qatar towards Arab- Israel Conflict under the rule of Sheikh Hamad ben Khalifa Al Thani, an unpublished Master Thesis, the Institute of Research, the University of Cairo, in Arabic.

IMF (2012).Qatar2012 Article IV consultation, IMF Country Report No.12/183International Monetary Fund. Publication Services. Washington

Ismail Sabri Maklad: Theories of international politics, F2, zat El Salasel, Kuwait, 1987, p. 158.

Jamal Zakaria Qassem: The Modern and Contemporary History of the Arab Gulf, the Evolution of British Influence in Emirates of the Arab Gulf and the International and Regional Conflicts, volume2, (1840-1914), 
the Dar Elfekr Alrabi, Cairo, p. 145.

Jeanne Hey, "Introducing Small States Foreign Policy" in: Jeanne Hey(ed.),Small States in World Politics: Explaining Foreign Policy Behavior (Colorado: Lynne Reiner Publishers,2003),pp.2-3.

Jihad Audah, the Strength Limit of the State of Qatar, cit, p72.

Mahmoud Sameer Al Rantisi: the Foreign policy of Qatar towards the Arab Spring countries and the Palestinian Case, Master thesis, Al- Aqsa University, 2013, p 33.

Milan Vassal, (Al-Jazeera Kicks up a Sand storm), The Middle East, No. 325, July - August 2002, p. 10.

Ministry of Foreign affairs Site, in Arabic: http://www.mofa.gov.qa/official

Mofeid El- Zaidi, Al - Jazeera Channel: Breaking the Taboos in the Arab Media, F1, Dar El - Talea for Printing and Publishing, Beirut, 2003, p96

Mofeid El Zaidi: Intellectual In the Arab Gulf, 1971-1938, a series of Doctoral Thesis (35), F1, the Center of Arab Unity Studies, Beirut, 2000, p45-46.

Mohamed Abdullah, Ukraine Build Silo for Grain Storage in the State of Qatar, Al Raya Newspaper, http://WWW.raya.comnews/pages/2fdeafd0-5bb6-4772-96cf-fbeac829753

Mohamed Abdullah, Ukraine Build Silo for Grain Storage in the State of Qatar, Al Raya Newspaper, in Arabic: http//WWW.raya.comnews/pages/2fdeafd0fbeac829753-96cf-4772-5bb6

Mohamed Alsayed Salem, the Concept of Regional Role, the "Twenty Second Annual Conference of Political Research: the contemporary developments of Egyptian regional role, the Center of Researches and Political Studies, Faculty of Economics \& Political Science, the University of Cairo, 30-31/ 12/2008, P6-9.

Mohamed Bin Eid Al Thani, Foreign Policy of Qatari in the Framework of the Gulf Cooperation Council (1981 1991), Master Thesis, Cairo: the University of Cairo, 1992. P135.

Mounzer Ahmed Zaki, the Foreign Policy of Qatar in the Light of Arab Political Transformations (2003 - 2012), Master Thesis, Al-Azhar University, Gaza, 2014, p63.

Muhammad I. A yish, The Changing of Arab Communication: Media Survival in the Information Age," in: Kais, Hafez (ed): Mass Maia, Politics and Society in the Middle East, New Jersey, Ham ptonPressinc, 2001, pp.118.

Mustafa Aliwi, the Middle East and the regional Role of Egypt, the Work of 10th Annual Conference of Political Research.

Mustafa Aliwi, the Middle East and the regional Role of Egypt, the Work of 10th Annual Conference of Political Research, Cairo, F. 7, 1-9/ December 1996, P313.

Naser Al Moujali: Does the Tour of Tamim re back Qatar to the Gulf Umbrella? Elaph site, 4/11/2013.

The site of the Foreign Policy of Qatar: http://www.mofa.gov.qa/official-statements.cfm

\section{Copyrights}

Copyright for this article is retained by the author(s), with first publication rights granted to the journal.

This is an open-access article distributed under the terms and conditions of the Creative Commons Attribution license (http://creativecommons.org/licenses/by/4.0/). 